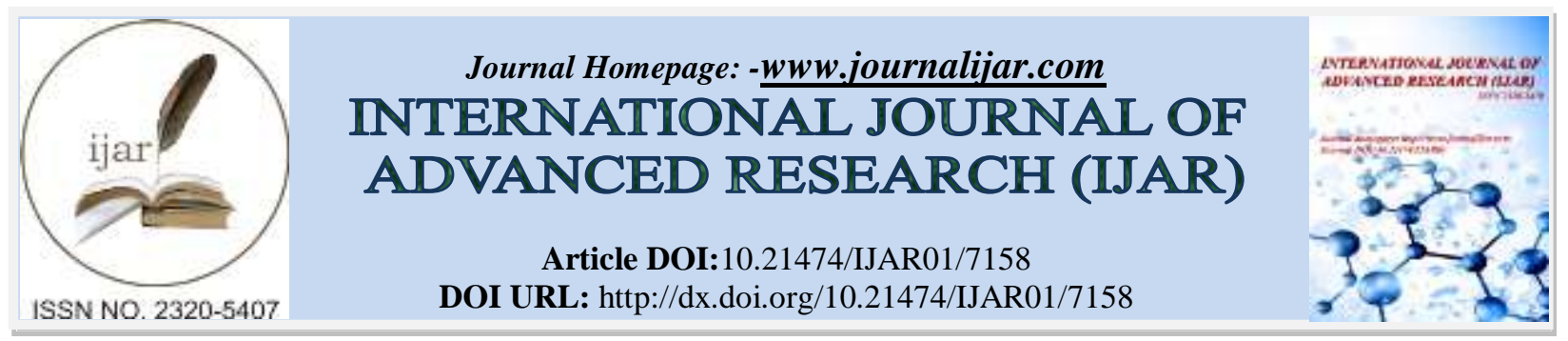

RESEARCH ARTICLE

\title{
URINARY TRACT INFECTION AMONG UNIVERSITY STUDENTS: EPIDEMIOLOGY, BACTERIOLOGY AND CLINICAL FEATURES.
}

\author{
Dr. Kadhim A. Al-Hilali, FRCP (Glasgow). \\ Al-Safwa University College, Karbala, Iraq.
}

\section{Manuscript Info}

Manuscript History

Received: 21 March 2018

Final Accepted: 23 April 2018

Published: May 2018

Keywords:-

UTI; university students; epidemiology; bacteruria; pyuria.

\section{Abstract}

Background: Urinary tract infection (UTI) is one of the most common problems encountered in urological outpatient clinics and in general medical practice. What so ever the etiology is, UTI needs proper management to prevent both morbidity and mortality events.

Objectives: The aims of the study were to pin point the prevalence of (UTI) among university students, the predominant causative microorganism and whether the infection is symptomatic or asymptomatic.

Patients and methods: One hundred twenty students (60 females and 60 males) were enrolled in the study for six months. Every student was asked to bring a sample of urine according to the standard guidelines of urine collection. Then urine sample was subjected to microscopic and culture examinations. Results were then statistically analysed.

Results: Pyuria was present in 25 students, 15 females and 10 males. Nine students (6 females and 3 males) showed symptoms of (UTI), the rest (13) were asymptomatic. Positive urine cultures (Bacteruria) were found in 22 students (14 females and 8 males). Escherichia Coli (E.coli) was the predominant identified uropathogen (71.1\%).

Conclusion: Urinary Tract Infection was common among University students with a prevalence rate of $(18.3 \%)$. Predominancy was in favour of females ( 1.75 females : 1 male). Asymptomatic cases were more common (59.1\%) as compared with symptomatic (40.9\%) cases. The predominant isolated uropathogen was E.coli.

Copy Right, IJAR, 2018,. All rights reserved.

\section{Introduction:-}

Urinary Tract Infection (UTI) is the most common bacterial infection encountered in general medical practice and accounts for 1 - 3\% of consultations (1). It affects all age groups ranging from neonates to the geriatric population, and about 150 million people worldwide are diagnosed with (UTI) each year (2). Financially the cost of community acquired UTI is significant, and cost the global economy in excess of six billion U.S Dollars $(2,3,4,5,6)$.

Involvement of the urethra, bladder, prostate, epididymis and testis is described as lower UTI. When the kidneys and ureters are affected, then it is called upper UTI. Transmission of bacteria to the urinary tract is more often via ascending transurethral route, but sometimes by blood stream or lymphatics (7). 
Urinary Tract Infection affects both sexes. However, it is more common in women, especially during the reproductive sexually active period. This is because of their short urethra, trauma during intercourse and the absence of bactericidial secretions $(8,9)$.

Urinary Tract Infection may be accompanied with symptoms (symptomatic UTI), such as dysuria, frequency, urgency, strangury and suprapubic pain if the lower urinary tract is involved. Upper (UTI) presents with fever, painful and tender loins. Urinary Tract Infection may be asymptomatic and discovered during routine checkups (1).

In (UTI) urine microscopic examination may show pus cells (white blood cells, WBCs) or red blood cells (RBCs). Pyuria is the presence of (6-10) or more pus cells per High Power Field (HPF) of unspun freshly voided mid-stream urine (10).

Pyuria can be a sign of bacterial (UTI), but may be (although rarely) sterile on culture. This is called sterile pyuria, which may be a sign of urinary tract tuberculosis, viruses, sexually transmitted diseases and some other causes (11, 12).

In general medical practice and outpatient clinics, one of the diagnostic criteria of (UTI) is based on symptoms plus microscopic findings of more than ten pus cells per high power field (HPF). This is especially applied in males, but definitive diagnosis depends on positive urine culture (13).

Sympomatic (UTI) needs treatment, while asympomatic infection does not need treatment, except in pregnant women, small children and cases of urinary tract abnormalities (1). The most common etiological pathogen causing (UTI) is E.coli (14). Urinary Tract Infections are generally self-limiting, but have the tendency to recur (15).

\section{Patients and methods:-}

The study was carried out on students of Al-Safwa University College, a private college in Karbala city, from January to June 2017 . The total number of students was 120 , sixty females and sixty males. Their ages ranged from 19 - 29 years, with a mean of $21.3 \pm 2.5$. The majority, $75 \%$ of them, was within the age group $19-22$ years as shown in table (1).

History and physical examinations were performed first, then, fresh mid-stream urine was collected from each student according to standard, sterile and aseptic techniques. Part of the urine was sent for microscopy. The other part was employed for culture on blood agar medium, incubated at $37.0^{\circ} \mathrm{C}$ for 24 hours. Significant growth was considered in case of colony count greater than $10^{5} \mathrm{cfu} / \mathrm{ml}$ (colony forming unit/ $\mathrm{ml}$ ). Isolates were identified by gram's stain and biochemical tests. The presence of $\boldsymbol{E}$. coli was further confirmed by the use of EMB agar media. The results were then analysed and evaluated statistically.

\section{Results:-}

Table (2) shows that the number of students with positive urine cultures, i.e., bacteruria were 22. Females were 14 $(63.6 \%)$ and males $8(36.4 \%)$. The incidence of $\boldsymbol{E}$. coli as an infecting uropathogen isolated from urine cultures was $71.1 \%$ as seen in table (3). Table (3) also shows international incidence results of the $\boldsymbol{E}$. coli.

Urine microscopy showed 25 students with pyuria, 15 females and 10 males. The number of symptomatic and asymptomaic Bacteruria are listed in table (4). The degree of severity of pyuria according to the number of WBCs (pus cells/HPF) are presented in table (5). The degree of severity of Bacteruria was assessed by urine culture, which means the heaviness of (UTI), is shown in table (6) in which each (X) symbol represents the number of bacteria per $\mathrm{ml}$ of urine (each $\mathrm{X}=10^{5} \mathrm{cfu} / \mathrm{ml}$ urine).

\section{Discussion:-}

All the students involved in the study were young individuals, as their mean age in years was $21.3 \pm 2.5 \mathrm{SD}$. The majority of them live under similar environment, housing conditions, water supply and socioeconomic status. It has been well known that (UTI) occurs in all age groups, mostly the age of reproductive life, and especially in the age group 20 - 30 years (2). These reported data were very close to results of the present study (Table 2). The incidence of (UTI) in females was far more common than in males due to anatomical and physiological factors (2). The study showed that female to male preponderances were 1.75 to 1.0 , respectively. 
Approximately half of all women have had a (UTI) by their twenties $(16,17)$, and about $20-30 \%$ of women with first (UTI) will have two or more infections later on (17). The incidence of (UTI) in this study was (18.3\%), female constituted $(63.6 \%)$ of cases compared with $(36.4 \%)$ for males as shown in table 2. Nevertheless the figure for males should be much less than this in comparison with what has been documented.

United Kingdom reports showed less prevalence of (UTI). The prevalence in women was $3 \%$ at the age of (20) years, increasing by about (1\%) each subsequent decade (1).

In the U. S. A. the incidence of (UTI) is difficult to precisely determine because it is not a reportable disease. Some reports and studies showed that half of all women would experience one (UTI) during their life time, and approximately eight to ten Million people in the U.S develop (UTI) each year the majority of them were women with a prevalence percentage of about $20 \%$ (18). In Brazil: the prevalence of (UTI) in elderly women was 16.55\% (19).

In Nairobi, Kenya, a study was carried out on antenatal women complaining of low abdominal pain. The prevalence of (UTI) was $26.7 \%$ (20). In Singapore $4 \%$ of young adult women were affected and the incidence increased to $7 \%$ at 50 years of age. Adult women were 30 times more likely than men to develop UTI (21). In Bangladesh, a study showed that the prevalence of UTI was $30 \%$ (20).

Although the incidence of micro-organisms associated with (UTI) showed variation in different countries, the E.coli remained the most prevalent uropathogen. In the present study the prevalence of E.coli was (71.1\%) compared with $73 \%$ in an Australasian study (23), 56.8\% in a Western study (24), $40 \%$ in a Pakistani study (25), $40 \%$ in a Kenyan study (20), $81 \%$ in a Bangladesh study (22) and $80-85 \%$ in a Nigerian study (26) as posted in Table (3).

In males diagnosis of UTI, depends on symptoms plus finding two - five or more of (WBCs) or 15 bacteria per HPF in a centrifuged urine sediment (27). In both sexes definite diagnosis depends on positive urine culture $\left(\geq 10^{5}\right.$ pathogenic bacteria/ml of urine) is termed bacteruria $(6,7)$. In medical practice and outpatient settings, urine culture is usually not performed and diagnosis simply depends on symptoms plus urine microscopy for pyuria $(6,13)$.

Bacteruria is most often associated with UTI. It may be symptomatic or asymptomatic which is more common in women and rises with age. Bacteruria is usually associated with pyuria, but not all cases of pyuria have Bacteruria $(1,28)$. In the present investigation, 22 students had Bacteruria UTI, 14 females $(63.6 \%)$ and eight males $(36.4 \%)$ as shown in table (2). Pyuria was present in 25 students of whom 15 were females (60\%) and 10 males (40\%). Asymptomaic Bacteruria was present in eight females, compared with six symptomatic cases as shown in table (4).

Usually the more the number of pus cells/HPF, the more severe is the UTI. In another word, patients with full field pus cells/HPF usually suffer from heavy or severe UTI as seen in table (5). On the same basis, the more the number of uropathogens/ml of urine, the more severe or heavy UTI as seen in table (6).

Table 1:- Age and sex distribution of the investigatedstudents sample.

\begin{tabular}{|c|c|c|c|c|}
\hline \multirow{2}{*}{ Age groups in years } & \multicolumn{2}{|c|}{ Gender } & \multirow{2}{*}{ Total } & Percentage of the total \\
\cline { 2 - 3 } & Female & Male & & $75 \%$ \\
\hline $19-22$ & 46 & 44 & 90 & $17.5 \%$ \\
\hline $23-26$ & 10 & 11 & 21 & $7.5 \%$ \\
\hline Over 26 & 4 & 5 & 9 & $100 \%$ \\
\hline Total & 60 & 60 & 120 & \\
\hline
\end{tabular}

Table 2:- Number of students with Bacteruria (Positive urine culture results).

\begin{tabular}{|c|c|c|}
\hline Gender & Number of students & Percentage of the total \\
\hline Female & 14 & $63.6 \%$ \\
\hline Male & 8 & $36.4 \%$ \\
\hline Total & 22 & $100 \%$ \\
\hline
\end{tabular}

$\mathrm{P}$ value $($ chi-square $=0.009)$. 
Table 3:- Urine culture results. Incidence of $\boldsymbol{E}$. coli bacteriaas compared with other international studies.

\begin{tabular}{|c|c|c|c|c|c|c|c|}
\hline $\begin{array}{l}\text { Name of } \\
\text { Bacteria }\end{array}$ & $\begin{array}{c}\text { University } \\
\text { student } \\
\text { sample }\end{array}$ & $\begin{array}{c}\text { Australasian } \\
\text { study }^{(a)}\end{array}$ & $\begin{array}{l}\text { Western } \\
\text { study }{ }^{(b)}\end{array}$ & $\begin{array}{l}\text { Pakistani } \\
\text { study }{ }^{(\mathrm{c})}\end{array}$ & $\begin{array}{l}\text { Kenyan } \\
\text { study }{ }^{\text {(d) }}\end{array}$ & $\begin{array}{l}\text { Bangladeshi } \\
\text { study }{ }^{(\mathrm{e})}\end{array}$ & $\begin{array}{l}\text { Nigerian } \\
\text { study }^{(\mathrm{f})}\end{array}$ \\
\hline E. coli & $71 \%$ & $73 \%$ & $56.8 \%$ & $40 \%$ & $40 \%$ & $81 \%$ & $80-85 \%$ \\
\hline
\end{tabular}

Table 4:- Gender difference among students with Pyuria, BacteruriaUTI and whether symptomatic or asymptomatic Bacteruria.

\begin{tabular}{|c|c|c|c|c|}
\hline Gender & \multirow{2}{*}{$\begin{array}{c}\text { No. and \% of students } \\
\text { with Pyuria }\end{array}$} & \multirow{2}{*}{$\begin{array}{c}\text { No. and \% of students } \\
\text { with Bacteruria (UTI) }\end{array}$} & \multicolumn{2}{|c|}{ No. and \% of students } \\
\cline { 4 - 5 } & $15(60 \%)$ & $14(63.6 \%)$ & $6(27.3 \%)$ & Symptomatic \\
\hline Female & $10(40 \%)$ & $8(36.4 \%)$ & $3(13.6 \%)$ & $5(22.7 \%)$ \\
\hline Male & $25(100 \%)$ & $22(100 \%)$ & $9(40.9 \%)$ & $13(59.1 \%)$ \\
\hline Total & $\leq 0.001$. & $\leq 0.001$ & & $\leq 0.0005$ \\
\hline P value & &
\end{tabular}

Table 5:- Degree of severity of pyuria according to the number of WBCs (pus cells / HPF).

\begin{tabular}{|c|c|c|}
\hline Number of WBCs/HPF & Number of cases & Percentage of the total \\
\hline $8-10$ & 2 & $8 \%$ \\
\hline $11-20$ & 5 & $20 \%$ \\
\hline$>20$ & 14 & $56 \%$ \\
\hline Fullfield & 4 & $16 \%$ \\
\hline Total & 25 & $100 \%$ \\
\hline
\end{tabular}

Table 6:- Degree of severity of bacteruria in culture positive cases.

\begin{tabular}{|c|c|c|}
\hline Number of cases & Degree of severity & \% of the total \\
\hline 9 & $\mathrm{X}$ & $40.9 \%$ \\
\hline 6 & $\mathrm{XX}$ & $27.3 \%$ \\
\hline 4 & $\mathrm{XXX}$ & $18.2 \%$ \\
\hline 3 & $\mathrm{XXXX}$ & $13.6 \%$ \\
\hline
\end{tabular}

Each $\mathrm{X}=10^{5} \mathrm{cfu} / \mathrm{ml}$ urine.

\section{References:-}

1. Goddard, J., Turner, A.N., Stewart, L.H., Urinary Tract Infection. In: Colledge, N.R., Walter, B.R., Ralston, S.H. (2010): Davidson's Principles and Practice of Medicine, $21^{\text {st }}$ edition, Edinburgh, Churchill Livingstone, pp: $469-472$.

2. Das A. and Banerjee, T. (2015): Prevalence of urinary tract infections and susceptibility pattern of uropathogens in women of Reproductive Group from north India. J. Advances in Medicine, 4 (1 - 2): 5 - 9.

3. Raju, S.B. and Tiwari, S.C. (2001): Urinary tract infection, A suitable approach. J. Indian Academy of Clinical Medicine, 2 (4):331 - 337.

4. Manjunath, G.N., Prakash, R., Annam, V. and Shetty, K. (2011): Changing trend in the spectrum of antimicrobial drug resistance pattern of uropathogens isolated from hospitals and community patients with urinary tract infections in Tumkur and Bangalore. Int. J. Biol. Med. Res., 2 (2): 504-507.

5. Ahmed, M.A., Shukla, G.S. and Bajaj, H.K. (2016): Incidence of urinary tract infections and determination of their susceptibility to antibiotics among pregnant women. International J. of Cell Science and Biotech., 5: 12 16.

6. Foxman, B. (2002) Epidemiology of urinary tract infection, incidence, morbidity and economic cost, Am. J. Med.,113 (1): 5 -13.

7. Yagoob, M.M. (2009): Urinary Tract Infection. In: Kumar, P., Clark, M. C. Kumar and Clark Clinical Medicine. $7^{\text {th }}$ edition, Edinburgh, Saunders, pp: 599 - 603.

8. Ronald, A. (2003): The etiology of urinary tract infections, traditional and emerging pathogens. Elsevier Inco. Disease, 49 (2): 71 - 82. 
9. Biswas, R., Rabbani, R., Ahmed, S.H., Sarker, M.A.S., Zafrin, N. and Rahman, M. (2014): Antibiotic sensitivity pattern of urinary tract infection at tertiary care hospital. Bangladish. Crit. Care J., 2 (1): 21 - 24.

10. Wikipedia the free encyclopedia (2017): Pyuria. Available at: https://en.wikipedia.org/wiki/pyuria

11. Wise, G.J. and Sehlejel, P.N. (2015): Sterile pyuria. New Eng. J. M. 372(11): 1048 - 1054.

12. Coming, A. (2005): The Renal System. In: Macleod's Clinical Examination, $11^{\text {th }}$ edition, Edinburgh, Churchill Livingstone. pp:194.

13. Mangula, M.G., Math, G.C., Patil, S.A., Gaddad, S.M. and Shivannavar C.T. (2013): Advances in Microbiology, 3: 473 - 478.

14. Farrel, D.J., Morissey, I., De Rubies, D., Robbins, M., Flemingham, D.A. (2003): UK multicenter study of the antimicrobial susceptibility of bacterial pathogens causing urinary tract infection. Journal of Infection, 46 (2): $94-100$.

15. Foxman, B. (2010): The epidemiology of urinary tract infection, Nature Review Urology, 7: 653 - 660.

16. Johnson, I.R. and Stam, W.E. (1980): Urinary tract infection in women: Diagnosis and Treatment. Ann. Intern. Med.,111: 906 - 917.

17. Foxman B. (1990): Recurring urinary tract infection: incidence and risk factors. Am. J. Public Health, 80: 331 333.

18. Khouri, D. and Swierzewski, S. (2015): Urinary tract infection overview. http://www.healthcommunities.com/urinary-tract-infection/overview-of-uti.shtml

19. Marques, L.P.J., Flores, J.T., Junior, O., Rodrigues, G., Mourao, C. and Moreira, R.M. (2012): Epidemiological and clinical aspects of urinary tract infection in community- dwelling elderly women. Braz. J. Infect. Dis., 16 (5): 436 - 441. Available at: http://dx.doi.org/10.1016/j.bjid.2012.06.025

20. Nabbugodi, W.T., Wanyoike, G. and Mugo, N.W. (2015): Prevalence of urinary tract infection, microbiological etiology and antibiotic sensitivity pattern among antenatal women presenting with low abdominal pains at Kenyatta-National Hospital, Nairobi, Kenya. J. Sci. Technol., 3: 6 pages. doi:10.11131/2015/101115.

21. Chee, W.T. and Maciej, P.C. (2016): Urinary tract infection in adults. Singapore Med. J. 57 (9): 485 - 490.

22. Bhowmick, B. K. and Rashid, H. (2004): Prevalence and antibiotic susceptibility of E.coli isolated from UTI in Bangladesh. Pakistan J of Bio Science, 7 (5): 717 - 720.

23. Aswan, S.M., Chandra Shiker, U.K., Shivashankara, K.N. and Pruthyi, B.C. (2014): Clinical profile of urinary tract infection in diabetics and non diabetics. Australasian Med. J., 7 (1): 29 - 34.

24. William, J.D., Thomlinson, J.L., Colo, J.G. and Cope, B. (1969): Asymptomatic urinary infection in gynecological outpatients. B. M. J. 1: 29.

25. Farooqui, R. Alam, M. and Kurshid, M. (1989): Urinary tract infection. J. Pakistani Med. Assoc., 39: 129 - 131.

26. Anuli, S.J., Clement, I. M. and Basseye, A. (2016): A review of the prevalence and predisposing factors responsible for urinary tract infection among adults, Pelagio Research Library. European J. Experimental Biology, 6 (4): 7 - 11.

27. Brusch, A.J. and Cunha, B. (2017): Urinary tract infection in males, Medscape, Sept. 19, 2017, available at: emedicine.staging.medscape.com/article/231574.

28. Hooton, T.M., Bradley, S.F., Cardenas, D.D., Colgan, R., Geerlings, S., Rice, J., Saint, S., Shaeffer, A., Tambayh, P., Tenke, P. and Nicole, L. (2010): Diagnosis, prevention and treatment of catheter associated urinary tract infection in adults. Clinical Infectious Disease, 50 (5): 625 - 663. 